\title{
Peak and Trough
}

I am not at a steady state.

I fear my half-lives are becoming cat lives.

(Perhaps I should have tried

veterinary school instead of allopathy.)

My classmates seem to have

peaks and troughs as I do,

measurements of

$\mathrm{x}$ and $\mathrm{y}$ axes of

varying names:

Sleep. Grade. Competence. Desperation.

But mine seem deeper

and wider.

I

feel

different.

\section{Andrew J McLean}

Correspondence to Andrew J McLean, Clinical Professor and Chair, Department of Psychiatry and Behavioral Science, University of North Dakota School of Medicine \& Health Sciences, 1919 Elm St. N., Fargo, North Dakota, US; andrew.mclean@med.und.edu

Competing interests None.

Provenance and peer review Not commissioned; internally peer reviewed.

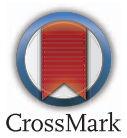

To cite McLean AJ. Med Humanit 2017;43:e4.

Published Online First 13 September 2016

Med Humanit 2017:43:e4. doi:10.1136/medhum-2016-011043 